\title{
E-learning Practices in North Cyprus Universities: Benefits, Drawbacks and Recommendations for Effective Implementation
}

\author{
Murat Hişmanoğlu (Corresponding author) \\ Faculty of Education, Akdeniz University \\ Dumlupinar Avenue 07058, Antalya, Turkey \\ Tel: 90-242-310-6941_E-mail: hismanoglu@gmail.com
}

\author{
Received: March 8, 2011 Accepted: April 21, $2011 \quad$ Published: November 1, 2011 \\ doi:10.5539/ies.v4n4p149 URL: http://dx.doi.org/10.5539/ies.v4n4p149
}

\begin{abstract}
The nature of higher education is changing in the world today. Rising tuition fees, reduced budgets, and an increasing need for distance education (New Media Consortium, 2007) are pushing educational institutions to reinvestigate how education is delivered. In line with this shifting context, e-learning is being practiced more and more frequently in higher education, providing modern and stimulating occasions for not only educational institutions but also students (Wagner, Hassanein and Head, 2008). Despite the relative benefits of e-learning in higher education, there are some challenges for disorganized, technology concentrated institutions, when attemping to put distance learning courses into practice. This article, therefore, aims at defining the concept of e-learning, providing an overview of e-learning in relation to higher education, expounding types of e-learning, listing benefits and drawbacks of e-learning, summarizing e-learning practices in North Cyprus universities and making recommendations for successful implementation of e-learning in North Cyprus higher education context.
\end{abstract}

Keywords: E-learning, Higher education, North Cyprus

\section{Introduction}

The nature of higher education is changing in the world today. Rising tuition fees, reduced budgets, and an increasing need for distance education (New Media Consortium, 2007) are pushing educational institutions to reinvestigate how education is delivered. In line with this shifting context, e-learning is being practiced more and more frequently in higher education, providing modern and stimulating occasions for not only educational institutions but also students (Wagner, Hassanein \& Head, 2008). As Volery (2000) states, universities will be left behind in the pursuit for globalization if they do not incorporate e-learning technology that is readily available into their systems. Ribiero (2002) stresses that universities must be totally familiar with the critical success factors related with offering online models of education if they are to enhance the prospective of e-learning as a device of delivering higher education.

Despite the relative benefits of e-learning in higher education, there are some challenges for disorganized, technology concentrated institutions, when attemping to put distance learning courses into practice. O'Hearn (2000) asserts that university structures are inflexible and unproven concerning the amalgamation of technological developments. By the same token, Holley (2000) indicates that e-learning is hard to implement without the full participation and approval of lecturers in that the degree of interaction between lecturers and students is still paramount in e-learning contexts (Volery, 2000). This article aims at defining the concept of e-learning, providing an overview of e-learning in relation to higher education, expounding types of e-learning, listing benefits and drawbacks of e-learning, summarizing e-learning practices in North Cyprus universities and making recommendations for successful implementation of e-learning in TRNC. In this article, some abbreviations were utilized by the author. The definitions of the abbreviations are given in the following:
TRNC: The Turkish Republic of Northern Cyprus
CHE: The Council of Higher Education
$E M U$ : Eastern Mediterrenean University
GNI: Gross National Income
GAU: Girne American University
$B B S$ : Billboard Systems
EUL: European University of Lefke
$E U C$ : Erasmus University Charter
EU: European Union
IT: Information Technology 
PDA: Personal Data Assistant

ENQA: The European Network for Quality Assurance

ICT: Information and Communications Technology

EADTU: European Association of Distance Teaching Universities

HECPAAC: Higher Education Council of Planning, Auditing, Accreditation and Coordination

\section{Definition of E-learning}

E-learning has been defined by researchers in different ways in the literature. Ong, Lai \& Wang (2004:1) define e-learning as the expression broadly deployed to describe "instructional content or learning experience delivered or enabled by electronic technologies". In general, e-learning refers to the use of the Internet, intranets/extranets, audio- and videotape, satellite broadcast, interactive TV, and CD-ROM, not only for content delivery, but also for interaction among participants (Industry Canada, 2001). In recent years, mobile and wireless learning applications have also been included in the expanded definition of e-learning (Kinshuk, Suhonen, Sutinen, \& Goh, 2003; Lehner, Nösekabel \& Lehmann, 2003).

\section{History of E-learning}

It was at the beginning of the $20^{\text {th }}$ century that the first "distance learning" in higher education was technically deployed at European universities. The teaching techniques in distance learning didn't alter much until the inclusion of television and radio as technological devices in the late 1950's, which paved the way for broadcasting a single lesson to a myriad of classrooms at a time. Although the main aim of broadcast instruction was to facilitate learning and cut costs, this model of distance learning could not substitute for the traditional teacher role or cope with the instructional quality of live instruction because of lack of interactivity. The decline of broadcast instruction gave rise to a shift back to traditional teaching in the 1970's, indicating that distance learning had no prospects. However, it was during the early 1980's that experimentation with online BBS and e-mail contributed to revitalizing the probability of powerful distance learning systems. This technology constituted a foundation for online instruction that is still employed today, albeit not being common until the later part of the decade. Distance learning initiatives exploded in Europe, Canada, the US, and Australia when universities commenced to present widespread worldwide-web portal access (Williams, 2004).

The term "e-learning" was coined in the early 1990's since the Internet permitted distance learning systems to incorporate curriculum and existing online technology to realize true bi-directional communication which could replace the conventional interaction between teachers and students. Clearly, changing correspondence classes into interactive online learning has been successfully made over the course of a hundred years' time, which indicates that problems facing e-learning in our times will normally have convenient solutions, and that finding them is a crucial task that should interest not only students but also instructors. Education Without Borders provides an opportunity for students to decide how the present-day obstacles to E-learning should be overcome, and to play a key role in enhancing the future of education worldwide (Williams, 2004).

In TRNC, the first e-learning practice commenced via the establishment of EMU Distance Education Institute in 2001. From the Fall Semester of 2000-2001 Academic Year on, under the support and supervision of Distance Education Institute, some courses in undergraduate and graduate programs of EMU were begun to be offered to students online (Aybay, 2002). EMU Distance Education Institute also initiated Information Management Undergraduate Program approved by CHE in 2002-2003 Academic Year. Furthermore, EMU Distance Education Institute put a project entitled Online Course Support into practice at the beginning of 2003. The aim of this project was to develop supplementary materials for students in relation to the courses delivered face to face, place sample questions and supplementary materials including lecture notes on the Web and allow all students getting education at Turkish universities to benefit from these materials (Aybay, 2004).

In 2006, Distance Education Center was established in GAU and thus it was aimed to coordinate and plan e-learning attempts of the university. In the Fall Semester of 2011-2012 Academic Year, EUL E-MBA program will start offering online education to students. Through E-MBA program, students will be able to follow courses as if they are in a real classroom setting, in the e-classroom supported by visual and oral input, they will be able to view the teacher, hear the teacher's voice. Furthermore, students will be able to make a voice chat / text chat with their peers. During live lessons, lecturers will be able to answer students' questions. Although e-learning is actively used in EMU and GAU in our times, it is expected that it will be employed in all universities in TRNC in the forthcoming years. 


\section{Types of E-learning}

Lancrin (2005) divides e-learning into three different categories: web-supplemented courses, web-dependent courses, and mixed mode courses. Web-supplemented courses concentrate on classroom-based teaching but contain components such as putting a course outline and lecture notes online, use of e-mail and links to online resources. Web-dependent courses require students to deploy the Internet for the main components of the program such as online discussions, assessment, or online project/collaborative work, but without prominent reduction in classroom time. In mixed mode courses, the e-learning component commences to substitute for classroom time. Online discussions, assessment, or project/collaborative work substitute for some face-to-face teaching and learning. However, prominent campus attendance remains part of the mix. And when courses are offered totally online, students can follow courses offered by a university in one city from another town, country or time zone.

\section{Benefits and Drawbacks of E-learning}

Fioriello (2009) lists the benefits of e-learning to students as follows:

$>$ One can register and get all blended learning courses on the World Wide Web context.

$>$ Students can learn autonomously when they want and where they want. E-Learning is self-paced and the learning sessions are accessible every time.

$>$ Students can arrange the course material based on their own needs and expectations. They can monitor their learning process and they can better comprehend the subject.

$>$ E- Learning gives fostering context to all individuals for learning methods.

$>$ Students get one central place for all course documents.

$>$ Students can have the opportunity for developed exchange with their peers and qualified teachers which rely on communication and information technologies.

$>$ E-learning supplies enhanced organization for regular studies like meeting assignment deadlines, homework, etc.

$>$ Students can reach their teachers on the Net and ask them for help in relation to their research studies.

$>$ Students can have an option to select what they like. E- Learning draws students' attention to topics that they like and enjoy.

The benefits of e-learning to teachers can be listed as follows:

$>$ The technique of teaching becomes more interactive.

$>$ Teachers can design one document for all types of students, so that they don't need to design it again and again.

$>$ Timing is also variable for teachers, they can do this with supplement to their regular classes in schools.

$>$ They can get more and more input on the Net, that they include in their course materials.

$>$ Interaction with students become more suitable. Students fear less and can ask their problems independently when sharing their problems with teachers because it's not face to face (Fioriello, 2009).

Despite a number of benefits of e-learning to the teachers and the learners, there are some drawbacks of e-learning to the teacher and the learner. According to Kruse (2004), drawbacks of e-learning to the teacher are as follows:

$>$ Up-front investment required of an e-learning solution is larger due to development costs. Budgets and cash flows will need to be negotiated.

$>$ Technology issues that play a factor include whether the existing technology infrastructure can accomplish the training goals, whether additional tech expenditures can be justified, and whether compatibility of all software and hardware can be achieved.

$>$ Inappropriate content for e-learning may exist according to some experts, though are limited in number. Even the acquisition of skills that involve complex physical/motor or emotional components (for example, juggling or mediation) can be augmented with e-learning.

$>$ Cultural acceptance is an issue in organizations where student demographics and psychographics may predispose them against using computers at all, let alone for e-learning.

The drawbacks of e-learning to the learners are as follows: 
$>$ Technology issues of the learners are most commonly technophobia and unavailability of required technologies.

$>$ Portability of training has become a strength of e-learning with the proliferation of network linking points, notebook computers, PDAs, and mobile phones, but still does not rival that of printed workbooks or reference material.

$>$ Reduced social and cultural interaction can be a drawback. The impersonality, suppression of communication mechanisms such as body language, and elimination of peer-to-peer learning that are part of this potential disadvantage are lessening with advances in communications technologies (Kruse, 2004).

\section{E-learning Practices in North Cyprus Universities}

In 1993, HECPAAC was founded as an autonomous body with juristic personality to plan, organize, observe the applications, audit and follow the accreditation procedures of the institutions of higher education, to channel their activities, to establish coordination between the institutions of higher education in the Turkish Republic of Northern Cyprus (http://www.ncyodak.eu/tr/default.htm).

Although HECPAAC has a key role in the enhancement of higher education in TRNC, the TRNC government's financial support to the HECPAAC and higher education institutions is rather low and not adequate. This small budget is not only impeding the desirable development in higher education but also decreases the probabilities for establishing proper e-learning centres in universities with high technological equipments and labs. Approximately, $10 \%$ of the North Cyprus budget is allocated to the universities (salaries, projects support) and 10\% is distributed as a direct student aid. The support of the state that is given to the higher education sector is relatively low compared to the outcome, which contains nearly $60 \%$ of the GNI. Despite having such financial and political difficulties, HECPAAC tries to adapt university education in TRNC to the EU's education program - to adopt Erasmus / Life Long Learning, to become a member of the EUC, to participate in the Bologna process and to become an associate member of the ENQA (Akalpler, 2009).

It is a positive development that HECPAAC became a partner of ENQA in 2007 and it attends seminars as an associate member (HECPAAC 2008 Year Activity Report, 15). Despite all these efforts for joining to the EU's education program and Bologna process, the prominence of the e-learning was disregarded. In the near future it is expected that $H E C P A A C$ will consider e-learning as a significant subject so as to offer quality in higher education. The reasons underlying this expectation are as follows (Akalpler, 2009):

\footnotetext{
$>$ E-learning increases communication and knowledge of people living in different countries in the world,

$>\quad$ E-learning contributes to the expansion of knowledge via e-library, e-work, and e-research,

$>\quad$ E-learning contributes to raising students' awareness of educational programs of different countries,

$>\quad$ E-learning increases equality in education and contributes to the regulation of program development in similar disciplines at the level of the European Union,
}

On the other side, some projects and programs were suggested by a variety of commissions of TRNC universities, $H E C P A A C$, Ministry of Education, and other units in order to implement the educational programs and projects of the European Union in TRNC. The project E-xcellence, EADTU is one of the prominent projects of European commission which has a significant role on fostering the e-learning for constituting standards of excellence in e-learning which will also promote the accreditation and evaluation of university programs in the EU countries and particularly in TRNC in which the e-learning is still in a hard and slowly growing process. In near future, it is assumed that awareness of TRNC universities regarding project E-xellence- EADTU will enhance to expand the e-learning program of the EU in TRNC (Akalpler, 2009).

Furthermore, through cooperation with the representatives of Turkish Republic universities, HECPAAC commenced to conduct another significant project providing the opportunity to deliver education to every part of TRNC in an electronic environment in 2008. Academics from Ankara University, Middle East Technical University and Gazi University take part in the project the budget of which is still not allocated.

The title of the conducted project is "Improving E-learning system in TRNC". The aim of the project is to establish an educational infrastructure independent from time and place to provide continuity in work related to the betterment of process and organization. Through this project, teachers will be able to better adapt themselves to innovations in the changing information age and there will a direct reflection of this process to their activities and the society. The steps to be followed are as follows:

- $\quad$ Setting up the infrastructure of e-learning 
- Developing an instructional model in the infrastructure of learning objects

- Developing e-learning software

- Developing educational materials
* Administration
* Regulations
* Operational
* Technical

- Application

The findings of the project will be utilized to meet the educational needs of the TRNC Ministry of Education and those of universities. Activities to be done on the so-called e-learning model are shown in the table below:

(Insert Table 1)

As seen in the table, while activities like new approaches in education, learner-centered teaching and methods and techniques of teaching will be performed for teachers in general, activities like testing and evaluation and materials design and use in new curricula will be done for subject teachers. As for primary education inspectors, activities like new approaches in education and learner-centered teaching will be performed for primary education inspectors.

Lectures to be delivered to the students through the channel of HECPAAC educational portal will be given in an intelligent classroom and/or in any environmet with Internet access. In parallel to the content of the course, while one camera will videotape the teacher, the other camera will videotape the whiteboard, presentation and other perspective of the classroom. By the help of sound- vision mixer, the suitable visual input will be transfered to the Internet. Moreover, documents placed in a content pool consisting of formerly prepared materials (sample word documents, presentations, sound files, etc.) can also be transferred to broadcasting (HECPAAC 2008 Year Activity Report, 42-45).

As it is seen, HECPAAC, though not being at the desired level, supports e-learning so as to provide quality in higher education. It is expected that the realization of the above mentioned project will make a great contribution to meet the educational needs of TRNC Ministry of Education and those of universities.

\subsection{E-learning Practices in North Cyprus Universities}

Due to lack of Internet infrastructure, insufficiency of rules and regulations, lack of e-learning or distance learning centers in universities, not training managers, teachers and students in the field of informational techologies and education, not informing them of these Technologies, insufficiency of technical infrastructure and that of man power, e-learning cannot be totally practiced in TRNC universities. However, in EMU and GAU, students are provided with e-learning programs actively. In some universities (for instance, EUL), e-learning will be put into practice in the near future. In the following section, information about TRNC universities that provide e-learning opportunities for students will be presented.

\subsubsection{E-learning practices in GAU}

GAU Distance Learning Center was established in 2006 to plan and coordinate the e-learning efforts of the university. The goal of the center can be stated as "Education, Anywhere, Anytime...". This can only be achieved via the right integration of education and technology.

Moodle, the e-Learning Portal, was opened to the public in March 2006 as a direct result of the e-learning strategy of the center. There are 5000 registered online users with 220 courses. The courses are a mixture of full on-line and blended. At GAU, students are networking with each other and electronic resources, often on the move using mobile technologies. The dynamic web-site offers a highly interactive tool which empowers the academia to provide quality learning opportunities using Blended Teaching and Learning Styles. Students are able to access the content anywhere, anytime, giving them a chance to study at their own pace. They can also contact their tutors and other students through the Moodle's online conferencing system, tutorials and informal study groups. (http://elearning.gau.edu.tr).

\subsubsection{The GAU e-learning system}

Moodle is a free and open source e-learning software platform, also known as a Course Management System, Learning Management System, or Virtual Learning Environment. Moodle is designed to help educators create online courses with opportunities for rich interaction. Its open source license and modular design means that people can develop additional functionality. 
The table below displays courses delivered online in GAU.

(Insert Table 2)

As seen in the table, the number of courses that are delivered online is high in Computers and Instructional Technologies Teaching Department (44), Management Information Systems Department (20), Faculty of Law (16) and Computer Engineering Department (16). However, the number of courses that are delivered online is low in Faculty of Communication (1), Institute of Science and Humanities (1), Life Long Center (2), Educational Administration and Supervision Department (2), and English Language Teaching Department (3).

\subsubsection{E-learning practices in EMU}

Distance Education Institute of EMU was founded to prepare, develop and put into practice online and distance education programs. In addition to offering two-year, undergraduate, and graduate degrees, the institute aims at making contribution to the learning process with certificate programs for new technologies and approaches in business applications. The main goals of the institute contain adopting student centered education methods, experimenting with distance education environments, and training individuals to end up with sufficient knowledge in this area (http://emuonline.emu.edu.tr/).

EMU-ONLINE is an academic program which is aimed at giving students flexibility in time and space, at the same time, giving them a chance of using the latest technology developed for computer-assisted learning. EMU-ONLINE program is run with the collaboration of concerned departments and instructors, and the Distance Education Institute of EMU. All EMU students who have full-time or part-time status, and who fulfill the requirements of a course are eligible for registration. A course taken from the EMU-ONLINE program is counted as a regular course (http://emuonline.emu.edu.tr/).

An EMU student is allowed to take at most one EMU-ONLINE course per semester, and a total of four courses in 4-year programs, or at most two courses in 2-year programs. If a student fails in an online course, he/she is not allowed to take any more EMU-ONLINE courses (http://emuonline.emu.edu.tr/). In the following table, some of the courses offered online in 2009-2010 Academic Year are presented.

(Insert Table 3)

As seen in the table, courses like ARCH 329, ARCH 509 were offered online in Architecture Department, courses like TOUR 506, TOUR 509 and STHM 412 were offered online in Tourism and Hospitality Department, the course ECON 431 were delivered online in Economics Department, the courses like ICELT and CCTD were delivered online in School of Foreign Languages, and the course WTGB was offered online in Computer Engineering Department.

In the following table, programs conducted online in 2009-2010 Academic Year are exhibited.

(Insert Table 4)

As seen in the table, programs such as Online Information Management Program, E-Hospitality Management Master's Program, e-Banking and Finance Masters Program (With Thesis), e-Banking and Finance Master's Program (Without Thesis) were conducted online in 2009-2010 Academic Year.

\subsubsection{E-learning practices in EUL}

EUL designed an e-MBA Programme to contribute to the formation of future executives with the vision and analytical skills that will provide them the opportunity to compete in the global business arena (http://lefkemba.org/). The table below exhibits the courses to be offered online in 2011-2012 Academic Year.

(Insert Table 5)

As exhibited in the table, courses such as Organizational Behavior, Marketing Management, Operation and Information Management \& Quantitative Technics, Accounting, Macro Economic Environment of the Firms and the Global Economics, Financial Management and Strategic Management will be offered as core courses in EUL in 2011-2012 Academic Year. However, courses such as International Marketing, Consumer Conduct, International Financial Management, Common Finance, Financial Institutions and Markets, and Marketing Research will be offered as elective courses in EUL in 2011-2012 Academic Year.

\section{Conclusion and Recommendations for Effective Implementation}

E-learning indicates the use of ICT to improve and/or foster learning in higher education. However, it may contain a myriad of systems, from students employing e-mail and accessing course work online while taking a campus-based course to programs offered totally online to the students (Lancrin, 2005).

E-learning can have probably main impacts on how higher education is shaped, done and presented. Although higher 
education institutions have been fixed in their composition and presentation of higher education courses up till now, demand for learning has never been so strong and this in line with the necessity to geographically widen learning may stimulate higher education institutions to offer e-learning initiatives. The same demands for learning and the maximized profits of autonomous educational providers have generated a real threat to the existence of the traditional university. It is e-learning which can provide universities with a tool of exceeding the newly constituted competition by making use of their traditional already constructed reputations (Singh, O'Donoghue, \& Worton, 2004).

E-learning programs indicate a change in teaching styles of teachers. Although the exact composition of the change is hard to quantify, allocation of adequate time and resources, integrated with administrative support, will assist the academic staff through the period of transition. Moreover, powerful management can assist educational institutions to cope with any increase in teacher workload by supplying effective use of resources (Singh, O'Donoghue, \& Worton, 2004).

Unlike traditional classroom learning, learning can take place outside the classroom context in e-learning. E-learning can help students become autonomous learners, which may assist them to become life long learners. Because teachers have the impact on removing students' technical frustrations, making them feel strong and stimulating students to cooperate with one another, the role of the teacher is key in the powerful implementation of e-learning (Singh, O’Donoghue, \& Worton, 2004).

Relevant to the implementation of e-learning, Nabeth, Angehrn \& Balakrishnan (2004) stress that higher educational institutions should be structurally stretchy and incorporate the potentials of distance learning as a device to foster general learning. Determining the most appropriate contexts and courses for e-learning delivery, higher education institutions can deploy these potentials successfully. In reality, an e-learning course blended with other more traditional face to face delivery methods can be said to be a successful e-learning course. According to Wolters (2003), giving more autonomy to the learner and at the same time making adaptation to less strictly monitored or supervised systems will constitute internal conflicts. These may not all be at the academic interface. The amalgamation of a variety of internal actions and practices as well as numerous IT systems will all mitigate against the effective implementation of a cohesive and helpful e-learning context. E-learning has a basic effect on the characteristic of higher education. Although the growth in demand can be provided by its implementation, higher education institutions should enhance programs which meet the needs and expectations of a wide range of learners (O’Neil, Singh and O’Donoghue, 2004).

In sum, as Lancrin (2005) states, better knowledge management has become key to effective implementation of e-learning. At this juncture, governments could make contribution to successful e-learning through:

$>$ Boosting the dissemination of good practices to encourage innovation, avoid wasteful duplication of endeavours, and scale up powerful experiments,

$>$ Stimulating suitable academic staff improvement to supply progress at institutional level,

$>$ Fostering research and improvement on learning objects and other innovations such as open educational resources or the deployment of virtual simulation devices and warrant their relation to students and faculty staff,

$>$ Unearthing the issues surrounding academic characteristic in e-learning,

$>$ Developing a dialogue between IT suppliers and institutions and fostering public-private partnerships so that costs remain at a reasonable level,

It should be stressed that the full involvement of educational institutions is crucial for better advancement of e-learning. Most significantly, governments and educational institutions should internalize an appropriate timeframe for enhancement. It is patience which is basic to any capacity-constructing policy. Only then can e-learning be incorporated to change traditional higher education system for the better in the long term (Lancrin, 2005).

Finally, as Sousa (2010) stresses, e-learning program should be designed in such a way that:

$>$ attributes importance to the setting and target group characteristics;

$>$ expounds the e-learning pros and cons in general, participants roles and responsibilities;

$>$ enables learners to study at any place at any time and enables them to select when and how to learn;

$>$ paves the way for problem/project-based learning, learning by doing, working on case studies or taking part in;

$>$ in small group sessions; 
$>$ is an integration of online and face-to-face activities;

$>$ facilitates synchronous audio/video communications;

$>$ paves the way for receiving immediate and constant feedback from the course teacher;

$>$ provides a virtual learning context, but is complemented with emerging Web2.0 tools and services.

\section{References}

Akalpler, E. (2009). The Impact of the E-learning in the Light of the EU's Higher Education Program and Accreditation Processes in North Cyprus Higher Education. Educational Research and Review. 4(5), $218-224$. [Online] Available: http://www.academicjournals.org/ERR (April 15, 2010)

Aybay, I. (2002, May). Eastern Mediterrenean University: EMU Online Experience. Paper presented at International Conference on Formal and Distance, Eskişehir.

Aybay, I. (2004). Distance Education Programs of Eastern Mediterrenean University. The Turkish Online Journal of Educational Technology. 3(2), 136-141

EMU Institute of Distance Education. (2010). [Online] Available: http://emuonline.emu.edu.tr (April 01, 2010)

EUL E-MBA. (2010). [Online] Available: http://lefkemba.org (March 20, 2010)

Fioriello, P. (2009). 14 Advantages of E-learning. [Online] Available: http://drpfconsults.com/14-advantages-of-e-learning (May 25, 2010).

GAÜ Uzaktan Eğitim Merkezi. (2010). [Online] Available: http://elearning.gau.edu.tr (March 10, 2010)

HECPAAC. [Online] Available: http://www.ncyodak.eu/tr/default.htm (June 10, 2010)

HECPAAC 2008 Year Activity Report. (2010). [Online] Available: http://www.ncyodak.eu/tr/files/yodakrapor.doc (June 05, 2010)

Holley, D. (2002). "Which room is the virtual seminar in please?" Education and Training. 44(3), 112-121. http://dx.doi.org/10.1108/00400910210424283

Industry Canada. (2001). The E-learning E-volution in Colleges and Universities: A Pan-Canadian Challenge. [Online] Available: http://www.cmec.ca/postsec/evolution.en.pdf (February 25, 2010)

Kinshuk, Suhonen, J., Sutinen, E., \& Goh, T. (2003). Mobile Technologies in Support of Distance Learning. Asian Journal of Distance Education. 1(1), 60-68

Kruse, K. (2004). Using the Web for Learning: Advantages and Disadvantages. [Online] Available: http://www.e-learningguru.com/articles/art1_9.htm (April 10, 2010)

Lancrin, S. (2005). E-learning in tertiary education. [Online] Available: http://www.nmm.html (April 25, 2010)

Lehner, F., Nösekabel, H., \& Lehmann, H. (2003). Wireless eLearning and Communication Environment. E-Services Journal. 2, 23-41. http://dx.doi.org/10.2979/ESJ.2003.2.3.23

Nabeth, T., Angehrn, A., \& Balakrishnan, R. (2004). Some reflections and researches for the design of the next generation e-Learning Systems for the knowledge intensive organization. INSEAD/CALT (the Centre for Advanced Learning Technologies) Working Paper 2004/02. http://dx.doi.org/10.1109/ICALT.2004.1357436

New Media Consortium. (2007). 2007 Horizon Report. [Online] Available: http://www.nmc.org/pdf/2007_Horizon_Report.pdf(May 10, 2010)

O'Hearn, J. (2000). Challenges for service leaders: setting the agenda for the virtual learning organization. International Journal of Contemporary Hospitality Management. 12(2), 97-106

Ong, C.-S., Lai, J.-Y., \& Wang, Y.-S. (2004). Factors affecting engineers' acceptance of asynchronous e-learning systems in high-tech companies. Information \& Management, $41 \quad$ (6), $795-804$. http://dx.doi.org/10.1016/j.im.2003.08.012

O’Neil, K., Singh, G., \& O’Donoghue, J. (2004). Implementing eLearning Programmes for Higher Education: A Review of Literature. Journal of Information Technology Education. 3(1), 313-323

Ribiero, T. (2002). From a distance: Look at distance learning's increased following. Education, 152(9), 85

Singh, G., O’Donoghue, J., \& Worton, H. (2004). A Study into the Effects of E-learning on Higher Education. Journal of University Teaching and Learning Practice, 14-24

Sousa, S. (2010). Handbook with Didactical and Practical Recommendations on E-learning Tools. [Online] 
Available: http://www.catelproject.net/Handbook\%20with\%20recommendations.pdf (January 20, 2011)

Volery, T. (2000). Critical success factors in online education. The International Journal of Educational Management. 14(5), 216-223

Wagner, N., Hassanein, K., \& Head, M. (2008). Who is responsible for e-learning success in higher education? A Stakeholder's analysis. Educational Technology and Society. 11(3), 26-36

Williams, M. (2004). E-learning: History and prospects. Education Without Boarders. [Online] Available: http://www.newsletter/htm (June 25, 2010)

Wolters, C. (2003). Understanding Procrastination From a Self-Regulated Learning Perspective. Journal of Educational Psychology. 95(1), 179-187. http://dx.doi.org/10.1037//0022-0663.95.1.179

Table 1. Activities to be done on the so-called e-learning model

\begin{tabular}{|c|l|l|}
\hline & Name of the activity & Target population \\
\hline 1 & New Approaches in Education & $\begin{array}{l}\text { Primary education inspectors } \\
\text { Teachers }\end{array}$ \\
\hline 2 & Methods and Techniques of Teaching & Teachers \\
\hline 3 & Learner-Centered Teaching & $\begin{array}{l}\text { Primary education inspectors } \\
\text { Teachers }\end{array}$ \\
\hline 4 & Testing and Evaluation & Subject teachers \\
\hline 5 & Materials Design and Use in New Curricula & Subject teachers \\
\hline
\end{tabular}


Table 2. Courses offered online in GAU

\begin{tabular}{|c|c|}
\hline Course categories & Number \\
\hline General Courses & 7 \\
\hline \multicolumn{2}{|l|}{ Faculty of Education } \\
\hline Computers and Instructional Technologies Teaching & 44 \\
\hline English Language Teaching & 3 \\
\hline \multicolumn{2}{|l|}{ Pre-School Teaching } \\
\hline Turkish Language and Literature Teaching & 4 \\
\hline Faculty of Engineering & 14 \\
\hline Computer Engineering & 16 \\
\hline Electrical and Electronics Engineering & 13 \\
\hline Industrial Engineering & 8 \\
\hline Faculty of Architecture, Design and Fine Arts & 4 \\
\hline Faculty of Administration and Economics & 4 \\
\hline Management Information Systems & 20 \\
\hline Faculty of Social Sciences & 11 \\
\hline Faculty of Communication & 1 \\
\hline Faculty of Law & 16 \\
\hline Nursery Vocational School & 4 \\
\hline Institute of Science and Humanities - M.A Programs & 4 \\
\hline Educational Administration and Supervision & 2 \\
\hline \multicolumn{2}{|l|}{ International Business Law } \\
\hline Management Information Systems & 6 \\
\hline Institute of Science and Humanities & 1 \\
\hline Management Information Systems & 4 \\
\hline Life Long Education Center & 2 \\
\hline English Preparatory School & 5 \\
\hline UNVA & 12 \\
\hline Others & 10 \\
\hline
\end{tabular}


Table 3. Courses offered online in EMU in 2009-2010

\begin{tabular}{|l|l|}
\hline Course Code & Course Name \\
\hline ARCH 329 & A Historical Survey of the Architecture and Art of Cyprus \\
\hline ECON 431 & Gender and Development \\
\hline STHM412 & Tourism Planning and Policy \\
\hline TOUR 506 & Financial Management in the Tourism and Hospitality Industry \\
\hline TOUR 509 & Contemporary Issues in International Hospitality and Tourism Management \\
\hline ARCH 509 & Analysis Techniques in Design \\
\hline ICELT & Cambridge ICELT Course \\
\hline CCTD & Certificate in Computers and Teacher Development (School of Foreign Languages) \\
\hline WTGB & Web Page Development and Technical Service (TRNC Ministry of Education) \\
\hline
\end{tabular}

Table 4. Programs conducted online in 2009-2010 Academic Year

\begin{tabular}{|l|}
\hline Name of the program \\
\hline Online Information Management Associate Degree Program \\
\hline E-Hospitality Management Master's Program \\
\hline e-Banking and Finance Master's Program (With Thesis) \\
\hline e-Banking and Finance Master's Program (Without Thesis) \\
\hline
\end{tabular}

Table 5. Courses to be offered online in 2011-2012 Academic Year

\begin{tabular}{|l|}
\hline Core Courses \\
\hline Organizational Behavior \\
\hline Marketing Management \\
\hline Operation and Information Management \&Quantitative Technics \\
\hline Accounting \\
\hline Macro Economic Environment of the Firms and the Global Economics \\
\hline Financial Management \\
\hline Strategic Management \\
\hline Electives \\
\hline International Marketing \\
\hline Consumer Conduct \\
\hline International Financial Management \\
\hline Common Finance \\
\hline Financial Institutions and Markets \\
\hline Marketing Research \\
\hline
\end{tabular}

